\title{
Protective Effects of Alpha-Lipoic Acid on Cerebral Vasospasm in Rats
}

\author{
- Hasan Ocak, [1] Evren Aydoğmuş, ${ }^{2}$ (1) Burak Bahadır, ${ }^{3}$

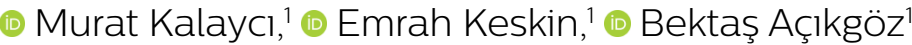

\begin{abstract}
'Department of Neurosurgery, Bülent Ecevit University Faculty of

Medicine, Zonguldak, Turkey

${ }^{2}$ Department of Neurosurgery, University of Health Sciences, Kartal Dr. Lütfi Kırdar Training and Research Hospital, İstanbul, Turkey ${ }^{3}$ Department of Pathology, Bülent Ecevit University Faculty of Medicine, Zonguldak, Turkey

Submitted: 26.05.2020 Accepted: 14.09.2020

Correspondence: Evren Aydoğmuş, SBÜ Kartal Dr. Lütfi Kırdar Eğitim ve Araştırma Hastanesi, Beyin ve Sinir

Cerrahisi Kliniği, İstanbul, Turkey E-mail: evren.aydogmus@gmail.com
\end{abstract}

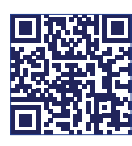

Keywords: Alpha-lipoic acid; cerebral vasospasm; subarachnoid hemorrhage.

By (reative Commons

\begin{abstract}
Objective: This study is an examination of the protective effects of alpha-lipoic acid (ALA) on cerebral vasospasm in an experimental rat model with subarachnoid hemorrhage (SAH) using biochemical, pathological, and histomorphometric analyses.
\end{abstract}

Methods: A total of 28 albino Wistar rats were randomly categorized into 4 groups $(n=7$ each): Group (G)I, no experimental intervention; $G 2$, subjected to $S A H ; G 3$, subjected to $\mathrm{SAH}$ and given physiological saline $(100 \mathrm{mg} / \mathrm{kg})$; and $\mathrm{G} 4$, subjected to $\mathrm{SAH}$ and treated with ALA (100 mg/kg).

Results: No statistically significant decrease in malondialdehyde level, the end product of lipid peroxidation, was observed among the drug groups (G3 and G4). Furthermore, there was no statistical increase in paraoxonase level, an endogenous antioxidant enzyme, among the drug groups (G3 and G4). Thin sections of the basilar artery were morphologically examined, and severe luminal narrowing and vessel wall thickening were observed in the SAH groups (G2 and G3). In the ALA group (G4), vessel wall thickness measurements revealed no statistically significant difference compared with the other SAH groups (G2 and G3); however, G4 rats were found to have larger luminal diameters than those in G3.

Conclusion: These findings suggest that ALA had no effect on malondialdehyde-associated lipid peroxidation and paraoxonase activity; however, it had a favorable effect on basilar artery luminal diameter in the treatment of cerebral vasospasm following $\mathrm{SAH}$.

\section{INTRODUCTION}

Cerebral vasospasm is a reversible complication of subarachnoid hemorrhage (SAH) that nonetheless has a high rate of morbidity and mortality. ${ }^{[1]}$ The pathogenesis of vasospasm after SAH is unclear. However, persistent luminal narrowing of the major cerebral arteries and oxidative stress mechanisms can be responsible for delayed cerebral injury after cerebral vasospasm. ${ }^{[2]}$

Alpha-lipoic acid (ALA; I,2-dithiolane-3-pentanoic acid) is an active organosulphur compound, synthesized by plants and animals (Fig. I). ${ }^{[3]}$ ALA is a powerful neuroprotective antioxidant, and has proven to be effective in the treatment of several oxidative stress-related diseases, such as diabetes, ischemic reperfusion damage, and cataract and radiation injury. ${ }^{[4-8]}$

The objective of this study was to examine the neuroprotective effects of the potent antioxidant ALA on cerebral vasospasm utilizing an experimental $\mathrm{SAH}$ model in rats and to evaluate the cellular changes through biochemical data and histomorphometric analysis of the basilar artery (BA).

\section{MATERIALS AND METHODS}

The experimental protocol was approved by the ethics committee of Bulent Ecevit University (date: 25.02.2008, decision no: 2008/02). The study was performed in the Experimental Surgery, Research, and Animal Laboratory of the Faculty of Medicine at Bulent Ecevit University. Forty 4-month-old female albino Wistar rats (average weight 225 g), were housed at $22^{\circ} \mathrm{C}-25^{\circ} \mathrm{C}$ with appropriate humidity and a 12-hour light/dark cycle and sufficient access to food and water. The rats were categorized into 4 groups $(n=7$ each): Group (G) I, no experimental intervention; G2, subjected to $S A H ; G 3$, subjected to $S A H$ and treated with physiologic saline (100 mg/kg); and $\mathrm{G} 4$, subjected to $\mathrm{SAH}$ and given ALA treatment $(100 \mathrm{mg} / \mathrm{kg})$. 


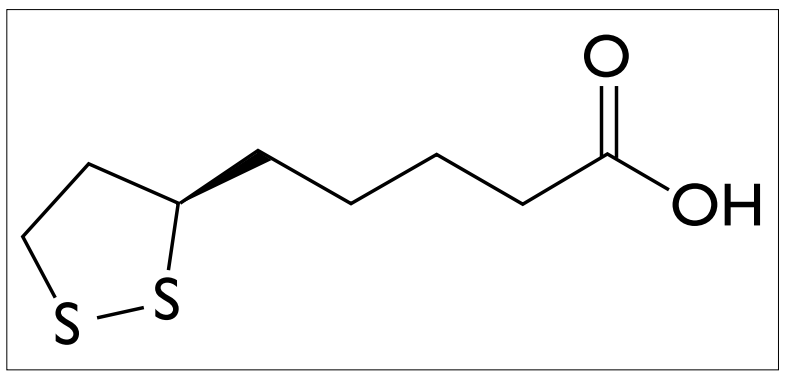

Figure 1. Molecular formula of alpha lipoic acid.

The experimental SAH model was established as described in previous studies. ${ }^{[1,9]}$ The rats were anesthetized with ketamine $(60 \mathrm{mg} / \mathrm{kg})$ and xylazine $(10 \mathrm{mg} / \mathrm{kg})$. Following the fixation of heads in a face-down position, the superior planes of the parietal bones were bent forward. Bleeding was induced through a posterior craniocervical approach. The arch of the atlas, the occipital bone, and the atlanto-occipital membrane were exposed through a suboccipital mini-incision. Approximately $0.30 \mathrm{~mL}$ of cerebrospinal fluid was percutaneously extracted through the cisterna magna in all of the groups except GI. Blood drawn from the tail artery was injected into the cisterna magna in the G2, G3, and G4 rats for approximately 2 minutes. The rats were then positioned face-down on an oblique plane for 15 minutes to increase blood flow to the basal cisternae. Following the initiation of $\mathrm{SAH}, 100 \mathrm{mg} / \mathrm{kg}$ physiological saline ( $0.9 \%$ sodium chloride) was intraperitoneally injected into the rats in the $\mathrm{G} 3$ group, and 100 $\mathrm{mg} / \mathrm{kg}$ ALA was intraperitoneally injected into the rats in the G4 group at 24-hour intervals for 48 hours.

Blood samples were taken from the tail arteries at the end of the 48-hour period using a previously defined procedure for anesthetic agents and the subjects were subsequently euthanized. Samples from the cerebral hemisphere were obtained for biochemical and histological evaluations. Samples from the pons and BA were post-fixed in $10 \%$ paraformaldehyde for 3 days and then embedded in paraffin for histologic and morphometric studies. ${ }^{[1,9]}$

The malondialdehyde (MDA) and serum paraoxonase (PON) enzyme activity levels in the brain tissue were evaluated. MDA is a highly reactive organic compound that is a result of lipid peroxidation. As a marker of lipid peroxidation, the level of MDA can be a means to assess membrane damage. ${ }^{[10]} \mathrm{PON}$ is a calcium-dependent aromatic esterase that plays an important role in protecting lowand high-density lipoprotein particles from oxidation. ${ }^{[I]}$ PON has an antioxidant effect against lipid peroxidation on cellular membranes and generates an anti-inflammatory response. ${ }^{\left[{ }^{\prime \prime}\right]}$ The rate of hydrolysis of PON was assessed by measuring the liberation of p-nitrophenol at $412 \mathrm{~nm}$ at $25^{\circ} \mathrm{C}$ according to the Eckerson method. ${ }^{[12]}$

After removal, all of the tissues were washed twice with cold saline, transferred to glass bottles and stored in a deep freezer $\left(80^{\circ} \mathrm{C}\right)$ until processing. Brain tissues were homogenized in 10 volumes of $150-\mathrm{mM}$, ice-cold potassium chloride using a glass-Teflon (The Chemours Compa- ny, Wilmington, DE, USA) homogenizer (IKA Ultra Turrax TI8 Basic; IKA Werke GmbH, Breisgau, Germany) for 2 minutes at $5000 \mathrm{rpm} .{ }^{\left[{ }^{[}\right]}$The supernatant used was obtained from the centrifusion of the homogenate at $5000 \mathrm{~g}$ for 15 minutes. High-performance liquid chromatography was performed using a Shimadzu system (Kyoto, Japan) with an MDA kit (Immundiagnostik AG, Bensheim, Germany).

For the histological examination, paraffin-embedded tissue samples from the pons and the BA were cut into sections of $5-\mu \mathrm{m}$ in thickness using a microtome. The sections were stained with hematoxylin and eosin (H\&E) and evaluated under a light microscope. Morphometric analyses were performed by the same pathologist using H\&E-stained sections obtained from the mid-sections of the BA under a light microscope (DMLB-I00S; Leica Microsystems $\mathrm{GmbH}$, Wetzlar, Germany) with Leica QWINPlus v.3.I.0 software (Leica Microsystems GmbH, Wetzlar, Germany). Each BA wall was evaluated from 4 points (locations corresponding to $3,6,9$, and 12 o'clock) and average values were obtained.

The measured values are represented as mean $\pm S D$, median, and minimum and maximum values. The compatibility of continuous variables with normal distribution was analyzed using the Shapiro-Wilk test. To compare the differences between the groups, a one-way analysis of variance with a Kruskal-Wallis test was used and a Bonferroni-corrected Mann-Whitney $U$ test was conducted to compare 2 statistically different medians in the 4 groups according to biochemical and morphometric data. Statistical significance was defined as $\mathrm{p}<0.05$ and all calculations were performed using SPSS Statistics for Windows, Version 17.0 software (SPSS Inc., Chicago, IL, USA). Statistical significance was defined as $\mathrm{p}<0.05$.

\section{RESULTS}

The MDA and PON values calculated at 48 hours are provided in Table I. No statistically significant differences were found between the groups regarding MDA $(p>0.800)$ or PON values $(\mathrm{p}>0.188)$.

Table I. Malondialdehyde (MDA) and paraoxonase (PON) values with median (min-max) and SD at 48 hours after subarachnoid hemorrhage

\begin{tabular}{lcc}
\hline Groups & $\begin{array}{c}\text { MDA (nMol/g tissue) } \\
\text { Median } \\
\text { (Min-Max) } \pm \text { SD }\end{array}$ & $\begin{array}{c}\text { PON (U/L) } \\
\text { Median } \\
\text { (Min-Max) } \pm S D\end{array}$ \\
\hline Group I $(n=7)$ & $143.5(69-202)$ & $43.38(22.52-88.32)$ \\
& $143.41 \pm 43.16$ & $48.79 \pm 24.56$ \\
Group 2 $(n=7)$ & $199.3(80-280)$ & $34.88(13.24-51.66)$ \\
& $179.78 \pm 79.22$ & $36.64 \pm 14.44$ \\
Group 3 $(n=7)$ & $\mid 49.1(73-223)$ & $30.57(12.8-82.8)$ \\
& $156.34 \pm 54.65$ & $30.18 \pm 30.69$ \\
Group 4 $(n=7)$ & $161(118-232.70)$ & $16.78(13.24-39.30)$ \\
& $164.80 \pm 30.48$ & $21.28 \pm 10.56$ \\
\hline
\end{tabular}



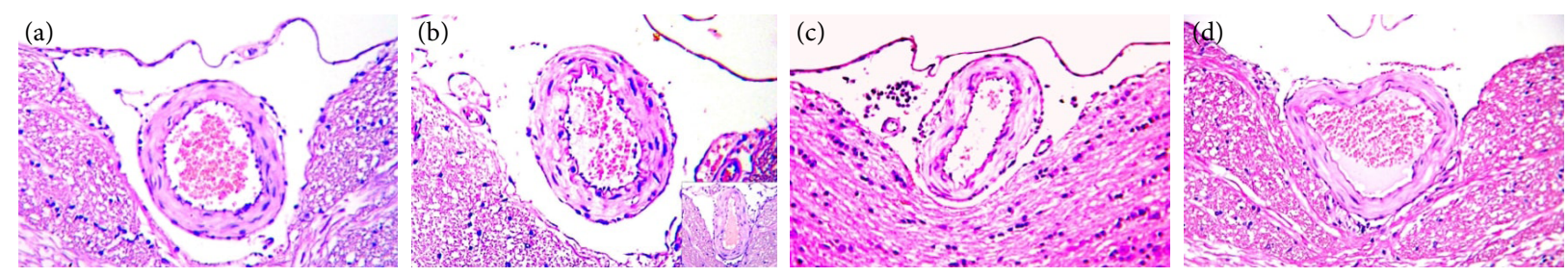

Figure 2. (a) Microscopic view of normal basilar artery in Group 1 (H\&E; x200). (b) Microscopic view of increased basilar artery wall thickness and luminal narrowing in Group 2 (H\&E; x200). (c) Microscopic view of increased basilar artery wall thickness and luminal narrowing in Group 3 (H\&E; x200). (d) Microscopic view of increased basilar artery luminal diameter in Group 4 (H\&E; x200).

Histologically, the structure of the BA in GI was consistent with that of normal rat cerebral arteries. Moderate swelling of the endothelium with focal desquamation, marked undulation of the internal elastic lamina, exceptionally thickened arterial walls, and luminal narrowing was observed in G2, G3, and G4. In G4 subjects, the arterial walls were significantly thinner, and the luminal diameters were larger than those of G2 and G3 (Fig. 2a-d).

The statistical analysis of the morphometric data of BA wall thickness and luminal diameter is shown in Table 2. Statistically significant differences were observed when GI and $G 2$ and $G 1$ and $G 3$ were compared based on their BA thickness and luminal diameter $(p<0.05$ and $p<0.05$, respectively). In addition, statistically significant differences were determined when $\mathrm{GI}$ and $\mathrm{G} 4$ and $\mathrm{G} 2$ and $\mathrm{G} 3$ were compared based on BA wall thickness; however, no significant differences were observed based on the luminal diameter $(p<0.05$ and $p<0.05$, respectively). According to BA wall thickness, there was no significant difference between G3 and G4; however, G4 presented with a larger luminal diameter than $G 3(p<0.05)$.

\section{DISCUSSION}

$\mathrm{SAH}$ is defined as blood between the arachnoid and pia membranes. Blood products in the subarachnoid space, free radicals, inflammatory processes, and neuronal and vasomodulatory mechanisms are involved in the development of vasospasm following SAH. Because vasospasm is strongly associated with delayed cerebral ischemia and clinical outcome, experimental studies primarily focus on the prevention of vasospasm. ${ }^{[13]}$ Delayed cerebral ischemia is a clinical syndrome associated with focal neurological and cognitive deficits, and even death, according to the level of cerebral ischemia, which may be concluded as cerebral infarction. ${ }^{[14]}$

Table 2. Basilar artery wall thickness and luminal diameters at 48 hours after subarachnoid hemorrhage

\begin{tabular}{lcc}
\hline Groups & Wall thickness & Luminal diameter \\
\hline Group I $(n=7)$ & $26.43 \pm 1.12$ & $100.24 \pm 2.38$ \\
Group 2 $(n=7)$ & $33.21 \pm 1.84$ & $91.50 \pm 3.99$ \\
Group 3 $(n=7)$ & $31.18 \pm 2.64$ & $85.24 \pm 10.89$ \\
Group 4 $(n=7)$ & $30.34 \pm 1.63$ & $99.82 \pm 10.43$ \\
\hline
\end{tabular}

Oxidative stress and mitochondrial dysfunction are primary mechanisms in the pathogenesis of several central nervous system diseases. ${ }^{[15]}$ Due to their ability to adjust the level of reactive oxygen species and metabolize excess free radicals, the potential neuroprotective effects of various antioxidant compounds have been assessed in earlier studies. ${ }^{[1,16]}$

The neuroprotective effect of ALA has been demonstrated in several animal models with cerebral ischemia reperfusion injury. ${ }^{[17]}$ Clark et al. ${ }^{[18]}$ indicated that ALA pre-treatment $(100 \mathrm{mg} / \mathrm{kg}$, subcutaneously) reduced stroke infarct volume and improved the neurological outcome in a focal cerebral reperfusion model.

ALA has free oxygen radical-scavenging and metal-chelating capacity; it also regenerates endogenous antioxidants, such as glutathione (GSH) and vitamins $E$ and $C .{ }^{\left[{ }^{[9]}\right.}$ Following intraperitoneal administration, ALA and its metabolite, dihydrolipoic acid, efficiently cross the blood-brain barrier and protect neuronal cells against lipid peroxidation by stimulating GSH synthesis in the astroglial cells in several brain regions because both are water- and lipid-soluble agents. ${ }^{[2]}$

Wang et al. ${ }^{[2]]}$ studied the neuroprotective effects of ALA in a rat model with middle cerebral artery occlusion and demonstrated a significant decrease in infarction volume and valuable improvement in the neurological status after dose-dependent administration of ALA.

Cellular proliferation in the arterial wall and endothelial cell apoptosis play an important role in the pathogenesis of cerebral vasospasm. Excessive ROS production can promote endothelial apoptosis. ALA enhances the activity of superoxide dismutase and GSH peroxidase, and prevents apoptosis and cerebral vasospasm by inhibiting lipid peroxidation. ${ }^{[22]}$ In 2015 , another study by Wei et al. ${ }^{[23]}$ investigated the protective effects of ALA in a rat model with traumatic brain injury and indicated that the administration of ALA resulted in the reduction of MDA concentrations; however, similar results were not observed in the present study.

According to our pathological results, ALA had beneficial effects on the BA luminal diameter and wall thickness in G4 compared with those of the SAH groups (G2 and G3). These findings are similar to those of a previous study, in which the therapeutic effects of ALA treatment on cerebral vasospasm were examined following experimental $\mathrm{SAH}$ in rabbits. ${ }^{[24]}$ 


\section{CONCLUSION}

The present study investigated the possible effects of ALA on cerebral vasospasm following experimental SAH in rats. According to our results, ALA treatment demonstrated no MDA-associated preventive effect on lipid peroxidation or PON-related antioxidant activity. In contrast, ALA provided significant dilation in luminal diameters. To understand the vasodilator effect of ALA on BA and its actual role in cerebrovascular events, further experimental studies using different variables other than MDA and PON are necessary. The results of our experimental rat model with SAH suggest that ALA treatment may contribute to the prevention of vasospasm.

Ethics Committee Approval

Approved by the local ethics committee (date: 25.02.2008, decision no: 2008/02)

Peer-review

Internally peer-reviewed.

Conflict of Interest

None declared.

\section{REFERENCES}

1. Aydogmus E, Gul S, Bahadir B. Neuroprotective effects of hesperidin on cerebral vasospasm after experimental subarachnoid hemorrhage in rats: Biochemical, pathologic, and histomorphometric analysis. World Neurosurg 2019;122:1332-7.

2. Munakata A, Naraoka M, Katagai T, Shimamura N, Ohkuma $\mathrm{H}$. Role of cyclooxygenase- 2 in relation to nitric oxide and endothelin-1 on pathogenesis of cerebral vasospasm after subarachnoid hemorrhage in rabbit. Transl Stroke Res 2016;7:220-7.

3. Shay KP, Moreau RF, Smith EJ, Smith AR, Hagen TM. Alpha-lipoic acid as a dietary supplement: molecular mechanisms and therapeutic potential. Biochim Biophys Acta 2009;1790:1149-60.

4. Bilska A, Wlodek L. Lipoic acid-the drug of the future. Pharmacol Rep 2005;57:570-7.

5. De Zwart LL, Meerman JH, Commandeur JN, and Vermeulen NP. Biomarkers of free radical damage applications in experimental animal and in humans. Free Radic Biol Med 1999;26:202-16.

6. Yang T, Xu Z, Liu W, Xu B, Deng Y. Protective effects of Alpha-lipoic acid on $\mathrm{MeHg}$-induced oxidative damage and intracellular $\mathrm{Ca}(2+)$ dyshomeostasis in primary cultured neurons. Free Radic Res 2016;50:542-56

7. Najafi R, Sharifi AM, Hosseini A. Protective effects of alpha lipoic acid on high glucose-induced neurotoxicity in PC12 cells. Metab Brain Dis 2015;30:731-9.

8. Khan J, Salhotra S, Ahmad S, Sharma S, Abdi SAH, Banerjee BD, et al. The protective effect of $\alpha$-lipoic acid against bisphenol A-induced neurobehavioral toxicity. Neurochem Int 2018;118:166-75.
9. Bederson JB, Germano IM, Guarino L. Cortical blood flow and cerebral perfusion pressure in a new noncraniotomy model of subarachnoid hemorrhage in the rat. Stroke 1995;26:1086-92.

10. Ohkawa H, Ohishi N, Yagi K. Assay for lipid peroxides in animal tissues by thiobarbituric acid reaction. Anal Biochem 1979;95:351-8.

11. Da Costa LA, Badawi A, El-Sohemy A. Nutrigenetics and modulation of oxidative stress. Ann Nutr Metab 2012;60:27-36.

12. Eckerson HW, Wyte CM, La Du BN. The human serum paraoxonase/ arylesterase polymorphism. Am J Hum Genet 1983;35:1126-38.

13. Etminan N, Vergouwen MD, Ilodigwe D, Macdonald RL. Effect of pharmaceutical treatment on vasospasm, delayed cerebral ischemia, and clinical outcome in patients with aneurysmal subarachnoid hemorrhage: a systematic review and meta-analysis. J Cereb Blood Flow Metab 2011;31:1443-51.

14. Rowland MJ, Hadjipavlou G, Kelly M, Westbrook J, Pattinson KT. Delayed cerebral ischaemia after subarachnoid haemorrhage: looking beyond vasospasm. Br J Anaesth 2012;109:315-29.

15. Bhat AH, Dar KB, Anees S, Zargar MA, Masood A, Sofi MA, Ganie SA. Oxidative stress, mitochondrial dysfunction and neurodegenerative diseases; a mechanistic insight. Biomed Pharmacother 2015;74:101-10.

16. Liu Y, Zhang Q, Wang L, Wang H, Sun T, Xia H, et al. The $\alpha$-lipoic acid improves high-fat diet-induced cerebral damage through inhibition of oxidative stress and inflammatory reaction. Environ Toxicol Pharmacol 2017;56:219-24.

17. Lv C, Maharjan S, Wang Q, Sun Y, Han X, Wang S, et al. $\alpha$-Lipoic Acid Promotes Neurological Recovery After Ischemic Stroke by Activating the Nrf2/HO-1 Pathway to Attenuate Oxidative Damage. Cell Physiol Biochem 2017;43:1273-87.

18. Clark WM, Rinker LG, Lessov NS, Lowery SL, Cipolla MJ. Efficacy of antioxidant therapies in transient focal ischemia in mice. Stroke 2001;32:1000-4.

19. Veskovic M, Mladenovic D, Jorgacevic B, Stevanovic I, de Luka S, Radosavljevic T. Alpha-lipoic acid affects the oxidative stress in various brain structures in mice with methionine and choline deficiency. Exp Biol Med 2015;240:418-25.

20. Arivazhagan P, Thilakavathy T, Ramanathan K, Kumaran S, Panneerselvam C. Effect of DL-alpha-lipoic acid on the status of lipid peroxidation and protein oxidation in various brain regions of aged rats. J Nutr Biochem 2002;13:619-24.

21. Wang Q, Lv C, Sun Y, Han X, Wang S, Mao Z, et al. The role of alpha-lipoic acid in the pathomechanism of acute ischemic stroke. Cell Physiol Biochem 2018;48:42-53.

22. Kolias AG, Sen J, Belli A. Pathogenesis of cerebral vasospasm following aneurysmal subarachnoid hemorrhage: Putative mechanisms and novel approaches. J Neurosci Res 2009;87:1-11.

23. Wei W, Wang H, Wu Y, Ding K, Li T, Cong Z, et al. Alpha lipoic acid inhibits neural apoptosis via a mitochondrial pathway in rats following traumatic brain injury. Neurochem Int 2015;87:85-91.

24. Erdi MF, Guney O, Kiyici A, Esen $H$. The effects of alpha lipoic acid on cerebral vasospasm following experimental subarachnoid hemorrhage in rabbit. Turk Neurosurg 2011;21:527-33. 


\section{Alfa Lipoik Asidin Sıçanlarda Serebral Vazospazm Üzerine Koruyucu Etkileri}

Amaç: Alfa lipoik asidin serebral vazospazm üzerindeki koruyucu etkilerini subaraknoid kanama ile deneysel bir sıçan modeli oluşturarak ve bu veriler üzerinde biyokimyasal, patolojik ve histomorfometrik analiz yaparak inceledik.

Gereç ve Yöntem: Toplam 28 Albino Wistar sıçanı rastgele dört gruba (her biri n=7) aşağıdaki şekilde gruplandırıldı: Grup (G) I, deneysel müdahale yok; Subaraknoid kanamaya maruz kalan G2; Subaraknoid kanamaya maruz kalan ve fizyolojik salin (I00 mg/kg) uygulanan G3; ve $\mathrm{G} 4$, subaraknoid kanamaya tabi tutulmuş ve alfa lipoik asit $(100 \mathrm{mg} / \mathrm{kg})$ ile uygulanan.

Bulgular: İlaç grupları (G3 ve G4) arasında lipit peroksidasyonunun son ürünü olan malondialdehit seviyelerinde istatistiksel olarak anlamlı bir azalma gözlenmedi. Ayrıca, ilaç grupları (G3 ve G4) arasında endojen bir antioksidan enzim olan paraoksonaz düzeylerinde istatistiksel bir artış olmamıştır. Baziler arter ince kesitlerinin morfolojik incelemesinde, subaraknoid kanama gruplarında (G2 ve G3) şiddetli luminal daralma ve damar duvarı kalınlaşması gözlendi. Alfa lipoik asit uygulanan grupta (G4) damar duvarı kalınlığı ölçümleri, diğer subaraknoid kanama gruplarına (G2 ve G3) kıyasla istatistiksel olarak anlamlı bir fark göstermemiştir; bununla birlikte G4, G3'ten daha büyük lümen çaplarına sahipti.

Sonuç: Bu bulgular alfa lipoik asidin malondialdehitle ilişkili lipit peroksidasyonu ve paraoksonaz aktivitesi üzerinde bir etkisi olmadığını; ancak subaraknoid kanamayı takiben serebral vazospazm tedavisinde baziler arter lümen çapları üzerinde olumlu etkileri olduğunu göstermektedir.

Anahtar Sözcükler: Alfa lipoik asit; serebral vazospazm; subaraknoid kanama. 